\title{
TÁRCSÁS ELEKTROSZTATIKUS SZÁLKÉPZŐ-BERENDEZÉS TERVEZÉSE ÉS KIVITELEZÉSE
}

\section{THE DESIGN AND IMPLEMENTATION OF A DISK ELECTROSPINNING DEVICE}

\author{
Hodgyai Norbert, ${ }^{1}$ Farmos Rudolf László, ${ }^{2}$ Gergely Attila ${ }^{3}$ \\ Sapientia Erdélyi Magyar Tudományegyetem, Marosvásárhelyi Kar, Gépészmérnöki Tanszék, \\ Marosvásárhely, Románia \\ ${ }^{1}$ hodgyai@ms.sapientia.ro \\ ${ }^{2}$ farmos_rudolf@ms.sapientia.ro \\ 3 agergely@ms.sapientia.ro
}

\begin{abstract}
The electrospinning procedure is a relatively simple and fast way of producing polymer fibers with diameters in the micrometer range. The one needle setup is commonly used due to its flexible design and effectiveness; however, this procedure has one major shortcoming; it has low productivity. The disk electrospinning design presented here combines the advantages of the corona and needleless electrospinning setups, namely the small solution surface area and high productivity. We used $33 \mathrm{wt} \%$ polyvinylpyrrolidone (PVP) solution to produce PVP fibers with the new design. The average fiber diameter of the produced PVP fibers was $\mathrm{d}=446 \pm 116 \mathrm{~nm}$, which is $\sim 25 \%$ larger compared to fibers produced with the one needle method.
\end{abstract}

Keywords: needleless electrospinning, disk electrospinning, polymer fibers, PVP, device design.

\section{Összefoglalás}

Az elektrosztatikus eljárás egy relatíve egyszerű és hatékony módja mikrométer nagyságrendủ átmérővel rendelkező polimerszálak előállításának. A szakirodalomban előszeretettel használt egy tűvel rendelkező variáns egyszerű és hatékony, viszont a termelékenysége alacsony. A bemutatott tárcsás elektrosztatikus berendezés ötvözi a korona és a tű nélküli elektrosztatikus berendezések előnyeit, vagyis kis oldatfelszín és nagy termelékenység. A tervezett berendezéssel sikeresen gyártottunk szálas szerkezetet 33\%-os polivinil-pirolidon- (PVP) oldatot használva. A keletkezett PVP-szálak átmérője d = 446 $1116 \mathrm{~nm}$, mely 25\%-kal nagyobb az egytűs módszerrel előállított PVP-szálak átlagos átmérőjénél.

Kulcsszavak: elektrosztatikus szálképzés, polimer szálak, PVP, tü nélküli elektrosztatikus szálképzés, tervezés.

\section{Bevezetés}

A mikrométer alatti szálátmérővel rendelkező polimerszálak előállítása elektrosztatikus eljárással nagy figyelmet kapott az elmúlt pár évtizedben. Az egyszerű gyártási eljárás, ill. nagy felület-térfogat arány miatt számos alkalmazási lehetőség felmerül. [1] Ezen hálók gyártása az esetek nagy részében egy egytűs elektrosztatikus szálképző eljárással készül, mely termelékenysége alacsony, és nem alkalmas nagyobb volumenű gyártás alkalmazására. A probléma megoldására több megoldás született, melyet a szakirodalom tárgyal. Ezen megoldások, korona-elektrosztatikus szálképző eljárást leszámítva [2-7], egy nagy oldatfelületet feltételeznek, ami alacsony forrásponttal rendelkező oldószer esetén párolgáshoz vezet, ami nem kívánatos. 
A dolgozat célja egy tű nélküli, tárcsás, elektrosztatikus szálképző berendezés tervezése és kivitelezése, amely kis oldatfelület használatával csökkentheti az oldatpárolgást.

\subsection{Egytüs elektrosztatikus szálképző eljá- rás bemutatása}

$\mathrm{Az}$ 1. ábra $\mathrm{az}$ egytűs elektrosztatikus szálképző berendezés vázát mutatja. A berendezésnek a következő alkotóelemei vannak: egy egyenáramú, nagyfeszültségű tápegység, egy tartály, mely a polimeroldatot tartalmazza, egy tủ, mely a tartállyal csővezeték segítségével kapcsolódik, valamint egy kollektor, mely a polimerszálak felfogására szolgál.

A polimeroldatot tartalmazó tartályból, amely az esetek nagy többségében egy fecskendő, egy csővezetéken keresztül jut el az oldat a fecskendő végén található tübe. A tű pozitív, míg a kollektor negatív vagy földpotenciálra van kapcsolva. A polimeroldatban a pozitív potenciál hatására pozitív töltések jelennek meg. A pozitív töltések a polimeroldatban taszítják egymást. A feszültség növelésével a pozitív töltések közti taszítóerő tovább növekszik. A folyadéksugár létrejön, amikor a töltések közti taszítóerő meghaladja az oldat felületi feszültségét a tü hegyén található folyadékcsepp felszínén. Az 1. ábra mutatja az ún. Taylor-kúpot is, mely a tű végén alakul ki [8]. Amíg a polimeroldat a tü hegyétől a kollektorig elér, az oldószer nagy része elpárolog, és a szál megnyúlik, így képezve az akár nanométer nagyságrendű átmérőt. [1, 9].

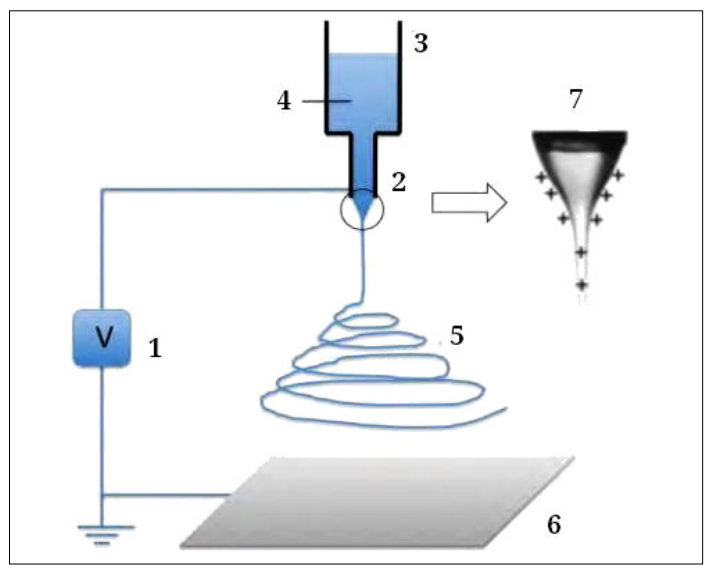

1. ábra. Polimerszálak előállítása elektrosztatikuszszálképzéssel polimeroldatból [11]. 1: nagyfeszültségütápegység, 2: szálképző elektróda(kapilláris), 3: oldatadagoló, 4: szálképzésifolyadék, 5: szálképzési térrész, 6: szálgyüjtö(földelt), 7: Taylor-kúp, vagyis a kapillárisbólkilépő folyadék deformált alakja

\subsection{Nagy teljesítményü elektrosztatikus szálképzési eljárások}

Az elektrosztatikus szálképzés teljesítménynövelésének legegyszerübb megoldása a kapillárisok számának növelése lenne, mely, habár a termelékenységet növeli, viszont a müködtetése problémás, és karbantartása nehézkes. [9, 10] A termelékenység növelése érdekében a kutatók kiküszöbölték a kapillárist a rendszerből, és egy folyadékfelszínt használtak. A polimeroldatban vezető mágneses részecskéket, hengereket, korongokat, fémhuzalokat vagy gömböket helyezve, ill. mozgatva vagy forgatva a felszínén, több Taylor-kúp kialakulásával több polimeroldat-sugár képződik, és így a termelékenység növekszik. [12] Ezen megoldások feltételezik egy folyadékfelszín létrehozását, ami magával vonja a használt oldószer elpárolgásának veszélyét, ill. a környezetből történő nedvességfelvételt. A koncentráció- és kompozícióváltozás negatív hatással lehet az elektrosztatikus szálképzési folyamatra. [13]

Molnár Kolos és társai egy olyan elektrosztatikus szálképzési technológiát fejlesztettek ki, mely nagy termelékenységgel képes polimerszálakat létrehozni, viszont nem használ nagy oldatfelszínt, így kiküszöböli a fent említett tűmentes megoldások hiányosságát. A szerkezet a 2. ábrán látható, melyet korona elektrosztatikus szálképzési eljárásnak neveztek el. [14]

A 3. ábrán látható berendezés egy vékony polimeroldat-réteget hoz létre a 2-es és 5-os egység közt, mely elősegíti több Tylor-kúp kialakulását, [8] és ezáltal megnöveli a termelékenységet, illetve megakadályozza az oldószer nagymértékű elpárolgását.

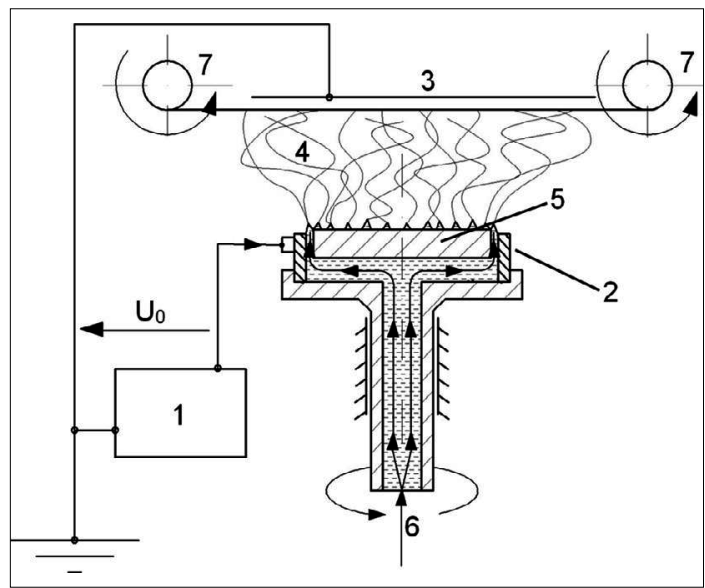

2. ábra. A tü nélküli elektrosztatikus szálképző berendezés vázlata [14] 


\section{Módszertan}

\subsection{Elektrosztatikus szálképzés}

Az elektrosztatikus szálképző eljáráshoz 33 tömeg \%-os PVP-oldatot használtunk, 75:25 (tömeg: tömeg) etanol:víz oldószerrendszerben. A tűs elektrosztatikus szálképző eljárás esetén $V=15 \mathrm{kV}$ potenciálkülönbséget, $F=0,7 \mathrm{~mL} / \mathrm{h}$ térfogatáramot és $D=10 \mathrm{~cm}$ tü-kollektor közti távolságot használtunk. A tárcsát $80 \mathrm{rpm}$, míg a futószalagot $100 \mathrm{rpm}$ fordulatszámon használtuk, $V=20 \mathrm{kV}$ és $D=10 \mathrm{~cm}$ mellett. Az oldatot az erre a célra kialakított üregbe fecskendeztük.

\subsection{Pásztázó elektron-mikroszkópos vizsgálat}

A pásztázó elektron-mikroszkópos vizsgálat egy JEOL JSM-5200-berendezésen volt kivitelezve. A mintákat $15 \mathrm{kV}$ feszültségen vizsgáltuk. A polimerszálak átmérőjének meghatározására az ImageJ programot használtuk.

\section{Eredmények}

\subsection{A tervezett berendezés bemutatása}

A tervezett berendezés kombinálja a tárcsás és a korona-elektrosztatikus eljárások pozitív tulajdonságait: a tárcsás felépítés egyszerü, míg a korona-elektrosztatikus eljárás kis folyadékfelszínt használ. A 3. és 4. ábrán látható berendezés müködési elve a következő: a tárcsa a forgómozgás következtében a palást felületére felhordja egy, erre a célra kialakított üregből az oldatot. A tárcsa felületén található oldatból a tárcsa sarkainál Taylor-kúpok alakulnak ki, és elkezdődik a szálképzés. Az üreg méretét a szerkezettel szemben állított elvárásoknak megfelelően minimalizáltuk, a párolgás csökkentése érdekében, viszont a szerkezetet úgy terveztük, hogy flexibilisen változtatható és viszonylag egyszerű legyen a tisztítása. Az ábrán látható, hogy egyszerre két tárcsát is használhatunk, mely a két különböző oldatból generál polimerszálakat, így kompozitszálas szerkezetet létrehozva. A tárcsa fordulatszámát egy potenciométerrel lehet változtatni.

A kollektor egy változtatható dőlésszögű futószalag, amely lehetővé teszi a termelékenység megnövelését és a keletkezett minta egyenletes vastagságát. A futószalag sebességét szintén egy potenciométer segítségével tudjuk változtatni.

\subsection{A PVP-hálok vizsgálata}

Az első lépésben a PVP-szálak generálásához az egytűs elektrosztatikus szálképző berendezést

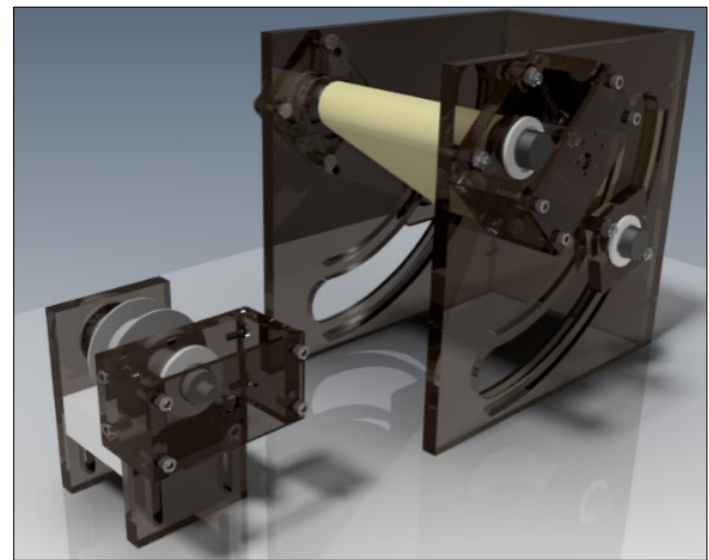

3. ábra. A tervezett tárcsás elektrosztatikus szálképző berendezés

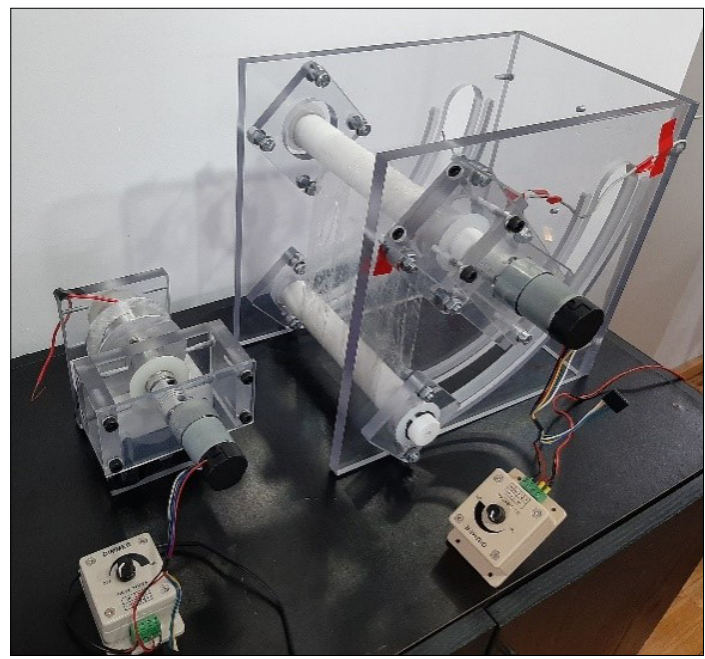

4. ábra. A megvalósított tárcsás szálképző berendezés.

használtuk, melynek felépítését részletesebben korábban közöltük. [15]. A PVP-szálak generálásához a tű és kollektor közti távolságot, $D, 10 \mathrm{~cm}$-re, illetve a térfogatáramot, $F, 0,7 \mathrm{~mL} / \mathrm{h}$-ra állítottuk. Ezen paraméterek mellett fokozatosan növeltük az alkalmazott potenciálkülönbséget, addig amíg beindult a szálképzési folyamat. Ebben az esetben ez 15 kV-nál következett be. Az 5. ábra mutatja a keletkezett szálas szerkezetet

$\mathrm{Az}$ 5.a. ábra SEM-felvételt megvizsgálva láthatjuk, hogy a szálas szerkezeten megjelentek gömbök, melyek a PVP-szálak mentén alakultak ki. Korábbi tapasztalatok alapján a gömbök 40\% oldatnál már nem jelentkeznek, így kialakulásuk nagy valószínűséggel a viszonylag alacsony koncentrációnak tudható be. Az 5.b. ábrán bemuta- 

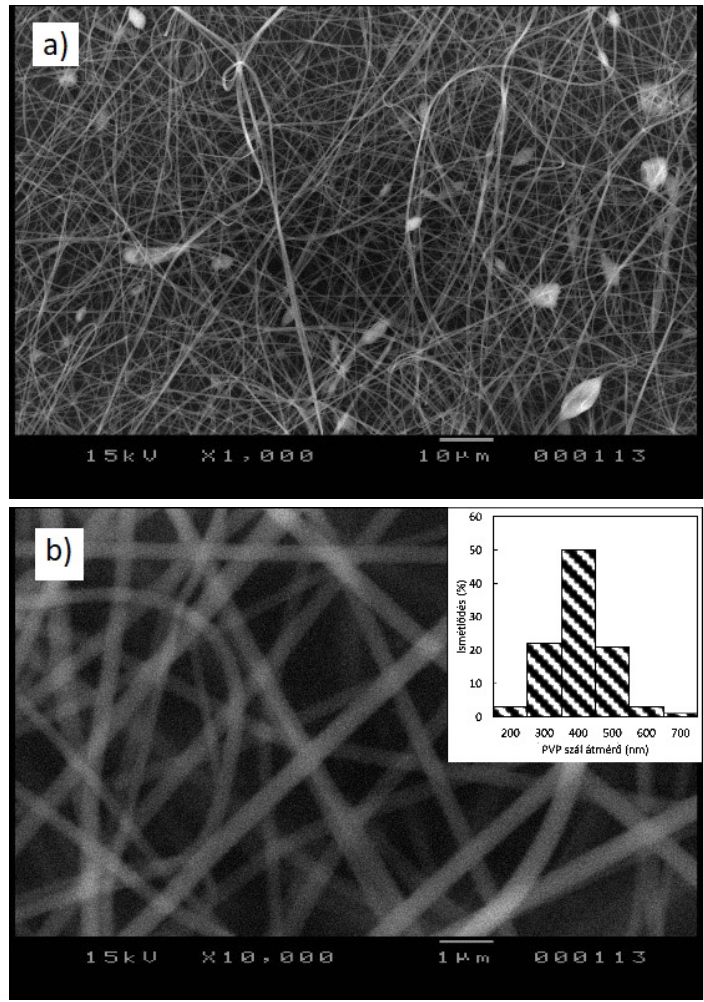

5. ábra. Az egytüs elektrosztatikus szálképzési berendezéssel generált szálas szerkezet a) x1000 és b) x10000 nagyításban készült SEM-felvétele

tott SEM-kép egy x10000 nagyítást mutat a keletkezett PVP-szálakról. Az eredmények feldolgozása $d=350 \mathrm{~nm}$ átlagos szálátmérő (1. táblázat) és $\sigma=86$ nm, szórást eredményezett. Az 5.b. ábrán a szálak átmérőjének hisztogramját is láthatjuk, amelynek vizsgálatából, illetbe a $\sigma$ értékből kiderül, hogy a keletkezett szálak átmérőjének szórása viszonylag alacsony.

A 6.a. ábrán látható SEM-felvétel azt a szálas szerkezet mutatja, melyet a tárcsával rendelkező elektrosztatikus szálképző eljárással állítottunk elő. A felvétel hasonló az 5.a. ábrához, miszerint göbök jelennek meg úgy az egytűs, mind a tárcsás előállítási eljárások esetén. A 6.b. ábrán a szálas szerkezet x5000 nagyításban látható. A keletkezett szálak sima felszínnel rendelkeznek, akárcsak az 5.b. ábra esetén. A hisztogram és a szálátmérők vizsgálata a tárcsás módszer esetén $d=446 \mathrm{~nm}$ és $\sigma=116$ nm-t eredményez. A szálátmérőértékekből látható, hogy a tárcsás módszerrel előállított PVP-szálak, az adott paraméterek mellett, átlagosan 100 nm nagyobb átmérővel rendelkeznek a
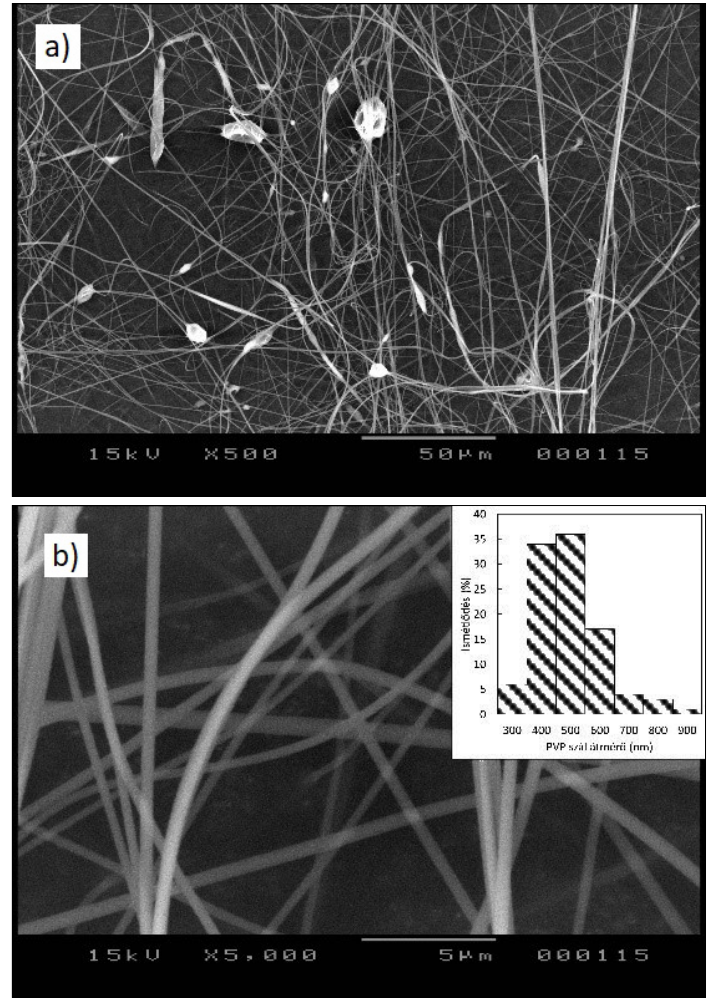

6. ábra. A tárcsával rendelkező elektrosztatikus szálképző berendezésen generált szálas szerkezet a) x500 és b) x5000 nagyításban készült SEM-felvétele.

tűs módszerhez képest. A szórási érték mindkét módszer esetén $25 \%$-a a $d$-nek.

A fentiekből levonhatjuk a következtetést, hogy a használt paraméterek mellett, a tárcsás módszerrel előállított szálas szerkezetek hasonló morfológiával rendelkeznek, mint az egytűs módszer, míg a keletkezett szálak átmérői nagyobbak 27 \%-kal. Mindkét módszer esetén a szórás értéke 25 \%-a a $d$-nek.

\section{Következtetések}

A bemutatott projekt keretében sikeresen megterveztünk és kiviteleztünk egy tárcsával rendelkező elektrosztatikus szálképző berendezést. A berendezés a termelékenységet hivatott növelni.

1. táblázat. PVP szál átmérők és szórás.

\begin{tabular}{|c|c|c|}
\hline & $\begin{array}{c}\text { Egytús } \\
\text { módszer }\end{array}$ & $\begin{array}{c}\text { Tárcsás } \\
\text { módszer }\end{array}$ \\
\hline $\mathrm{d}(\mathrm{nm})$ & 349 & 446 \\
\hline$\sigma(\mathrm{nm})$ & 86 & 116 \\
\hline
\end{tabular}


A tárcsás módszert a jól ismert egytűs módszerhez hasonlítottuk. Az eredmények alapján a két módszerrel hasonló morfológiájú szálas szerkezetet sikerült előállítani, míg a PVP-szálak átmérője a tárcsás módszer estén átlagosan 100 nm-rel nagyobb a tűs módszerrel előállított mintákhoz képest.

\section{Szakirodalmi hivatkozások}

[1] Huang Z.-M., Zhang Y.-Z., Kotaki M., Ramakrishna S.: A review on polymer nanofibers by electro-spinning applications in nanocomposites. Composites Science and Technology, 63/15. (2003) 2223-2253. https://doi.org/10.1016/S0266-3538(03)00178-7

[2] Yarin A. L. , Zussman E.: Upward Needleless Electrospinning of Multiple Nanofibres. Polymer, 2004, 45, 2977-2980. https://doi.org/10.1016/j.polymer.2004.02.066

[3] Jirsák O., Sanetrnik F., Lukas D., Kotek V., Martinova L., Chaloupek J.: US Patent W02005024101, 2005.

[4] Li J, Gao F, Liu L.Q., Zhang Z.: Needleless electro-spun nanofibers used for filtration of small particles. Express Polymer Letters, 7/8. (2013) 683-689.

https://10.3144/expresspolymlett.2013.65

[5] Jentzsch E., Gül Ö., Öznergiz E.: A comprehensive electric field analysis of a multifunctional electrospinning platform. Journal of Electrostatics, 71/3. (2013) 294-298.

https://doi.org/10.1016/j.elstat.2012.12.007

[6] Forward K. M., Flores A., Rutledge G. C.: Production of core/shell fibers by electrospinning from a free surface. Chemical Engineering Science, 104. (2013) 250-259.

[7] Niu H., Wang X., Lin T.: Needleless electrospinning: Influences of fibre generator geometry. Journal of the Textile Institute 103/7. (2012) 787-794. https://doi.org/10.1080/00405000.2011.608498
[8] Taylor G. I.: Electrically driven jets. Proceedings of Royal Society A, 313/1515. (1969) 453-475.

https://doi.org/10.1098/rspa.1969.0205

[9] Athira K., Sanpui P., Chatterjee K.: Fabrication of Poly (Caprolactone) Nanofibers by Electrospinning. Journal of Polymer and Biopolymer Physics Chemistry, 2/4. (2014) 62-66.

[10] Reneker D. H., Yarin A. L.: Electrospinning jets and polymer nanofibers. Polymer, 49/10. (2008) 2387-2425.

https://doi.org/10.1016/j.polymer.2008.02.002

[11] Theron S. A., Yarin A. L., Zussmann E., Kroll E.: Multiple jets in electrospinning: experiment and modeling. Polymer, 46/9. (2005) 2889-2899.

[12] E. Hirsch, P. Vass, B. Démuth, Zs. Pethő, E. Bitay, S. K. Andersen, T. Vigh, G. Verreck, K. Molnár, Zs. K. Nagy, Gy. Marosi: Electrospinning scale-up and formulation development of PVA nanofibers aiming oral delivery of biopharmaceuticals. Express Polymer Letters, 13/7. (2019) 590-603.

https://doi.org/10.3144/expresspolymlett.2019.50

[13] Kim G. H., Cho Y.-S., Kim W. D.: Stability analysis for multi-jets electrospinning process modified with a cylindrical electrode. European Polymer Journal, 42/9. (2006) 2031-2038.

https://doi.org/10.1016/j.eurpolymj.2006.01.026

[14] Molnar K., Nagy Z. K.: Corona-electrospinning: Needleless method for high-throughput continuous nanofiber production. European Polymer Journal, 74. (2016) 279-286.

https://doi.org/10.1016/j.eurpolymj.2015.11.028

[15] Gergley A., Kantor J., Bitay E., Biro D.: Electrospinning of Polymer Fibres Using Recycled PET. Acta Materialia Transylvanica 2/1. (2019) 19-26. https://doi.org/10.33924/amt-2019-01-04 